\title{
Minimal Invasion Present
}

National Cancer Institute

\section{Source}

National Cancer Institute. Minimal Invasion Present. NCI Thesaurus. Code C65201.

A morphologic finding indicating the infiltration of the stroma immediately adjacent to a carcinoma in situ by isolated malignant cells or small groups of malignant cells. 